\title{
Reirradiation for Recurrent Meningioma
}

\author{
N. Ohri \\ Thomas Jefferson University and Hospitals
}

A. Wojcieszynski

Jefferson Medical College

\section{J. J. Evans}

Thomas Jefferson University and Hospitals

D. W. Andrews

Thomas Jefferson University and Hospitals

M. Werner-Wasik
Thomas Jefferson University and Hospitals

Follow this and additional works at: https://jdc.jefferson.edu/bodinejournal

Part of the Oncology Commons

Let us know how access to this document benefits you

\section{Recommended Citation}

Ohri, N.; Wojcieszynski, A.; Evans, J. J.; Andrews, D. W.; and Werner-Wasik, M. (2010) "Reirradiation for Recurrent Meningioma," Bodine Journal: Vol. 3 : Iss. 1 , Article 38.

DOI: https://doi.org/10.29046/TBJ.003.1.037

Available at: https://jdc.jefferson.edu/bodinejournal/vol3/iss1/38

This Article is brought to you for free and open access by the Jefferson Digital Commons. The Jefferson Digital Commons is a service of Thomas Jefferson University's Center for Teaching and Learning (CTL). The Commons is a showcase for Jefferson books and journals, peer-reviewed scholarly publications, unique historical collections from the University archives, and teaching tools. The Jefferson Digital Commons allows researchers and interested readers anywhere in the world to learn about and keep up to date with Jefferson scholarship. This article has been accepted for inclusion in Bodine Journal by an authorized administrator of the Jefferson Digital Commons. For more information, please contact: JeffersonDigitalCommons@jefferson.edu. 


\title{
Reirradiation for Recurrent Meningioma
}

\author{
Ohri, N., ${ }^{1}$ Wojcieszynski, A., ${ }^{2}$ Evans, J.J., ${ }^{3}$ Andrews, D.W., ${ }^{3}$ Werner-Wasik, M.. ${ }^{1}$ \\ ${ }^{1}$ Department of Radiation Oncology, Thomas Jefferson University and Hospitals, Philadelphia, PA \\ 2Jefferson Medical College, Thomas Jefferson University, Philadelphia, PA \\ ${ }^{3}$ Department of Neurological Surgery, Thomas Jefferson University and Hospitals, Philadelphia, PA
}

\section{Purpose/Objective(s)}

Management options for meningioma include observation, surgical resection, and radiation therapy (RT). In cases of progressive or recurrent disease after RT, similar options exist. The control rate following a second course of RT is unknown.

\section{Material/Methods}

We reviewed an institutional database of patients treated with stereotactic radiosurgery (SRS) or fractionated stereotactic radiotherapy (fSRT) for meningioma. Patients who underwent two or more courses of RT for disease recurrence or progression were identified. Clinical, treatment, and outcome data for these patients were recorded. Disease progression was defined as documented growth on follow-up imaging or additional intervention.

\section{Results}

Six-hundred-fifty-one (651) patients were treated with RT for meningioma from 1995 to 2009. Of those, 18 patients who underwent reirradiation for recurrent or progressive meningioma and follow-up imaging were identified. Thirteen (13) patients underwent surgical resection before the first course of RT, and 6 patients underwent surgical resection between courses of RT. Median interval between courses of RT was 42 months (range 3-93). Ten (10) patients were treated with SRS (14-18 Gy), and 8 were treated with fSRT (35.0-54.0 Gy).

With median follow-up time of 31 months (range 2-105), 11 patients (61\%) were found to progress after reirradiation, at a median of 10 months (range 5-57) following completion of treatment. KaplanMeier estimates of freedom from progression (FFP) at 1, 2, and 3 years were $65 \%, 65 \%$, and $49 \%$, respectively.

Seven patients (39\%) were shown to have atypical or malignant histology on biopsy or surgical resection at some point in their treatment course. Median time to progression for these patients was 8 months. Median time to progression has not been reached for other patients. FFP at 1 year for patients with atypical or malignant tumors was $17 \%$, compared to $90 \%$ for grade $1 /$ unbiopsied tumors $(\mathrm{p}<0.01)$.

\section{Conclusion}

Reirradiation for recurrent or progressive meningioma yields modest tumor control rates. Outcomes are poor in patients with high-grade tumors. 